\title{
영국과 아일랜드 개발교육 사례의 정책적 함의
}

박수연 (KOICA ODA교육원 전문관)

\section{목 차}

I. 들어가며

II. 개발교육의 개념과 필요성

III. 영국과 아일랜드 개발교육 사례 분석

1. 영국의 개발교육

2. 아일랜드의 개발교육

IV. 한국 개발교육에의 정책적 함의

V. 나가며

\section{I. 들어가며}

반 세기 만에 전쟁의 폐허 위에서 고도 경제성장과 민주화를 이룩하며, 한강의 기적을 이루었다고 칭송받는 대한민국은 현재 빠른 속도로 국제개발계에서도 주요한 주체로 자리매김하고 있다. 한국은 2010년 OECD 개발원조위원회(Development Assistance Committee, DAC)에 가입함으로 원조 선진국 그룹의 일원이 되었다. 같은 해 1 월 국제개발협력기본법을 제정하고, 10 월에는 국제개발협력 선진화 방안을 마련하였다. 2010년 G20의 의장국으로 서울 G20 회의를 성공적으로 개최하였으며, 2011년에는 부산 세계개발원조총회를 성황리에 마쳤다. 김성한 전 외교부 장관은 Post-2015 Development Agenda를 구성하는 High Level Panel의 전 세계 27인 중 한명으로 UN 사무총장에게 제출하는 보고서를 완료하는 임무를 감당하였다. 또한 한국은 부산글로벌파트너십 집행위원회에서 미국, 영국, EU와 함께 공여국 대표로 선출되어 활동 중이다. 마지막으로 다가오는 2015년에는 태국 
좀티엔(Jomtien)에서의 World Conference on Education for All과 세네갈 다카르(Dakar)에서의 World Education Forum의 대를 잇는 제 3 차 세계교육포럼이 인천에서 개최될 예정이다.

한국 내에서 국제개발에 대한 정치적 지지는 지속적으로 이루어져 현 박근혜 정부 아래에서도 정부의 140 개 국정과제 중 하나로 "ODA 지속 확대 및 모범적, 통합적 개발협력 추진"을 내걸고 ODA 규모를 지속적으로 확대하고 있다. (전규석 2013) 한국정부는 2010년 10월에 발간한 '국제개발협력 선진화 방안'에서 한국의 ODA/GNI 비율을 2015 년까지 $0.25 \%$ 까지 확대하는 것을 목표로 하고 있다. 실질적으로 우리나라의 ODA/GNI 비율은 지속적으로 상승하여 2008년 0.09\%, 2009년 0.1\%, 2010 년 $0.12 \%$ 를 지나 2012년에는 $0.14 \%$ 까지 자금을 확대해왔다. 이러한 지속적인 원조 확대에 있어서, $\mathrm{ODA}$ 에 대한 국민의 지지는 필수적이다. 이에 2013년 2월 개최된 제 15 차 국제개발협력위원회에서는 2013년도 주요추진과제 중 하나로 ODA 통합홍보계획을 설정하고, 그 일환으로 ODA 백서(White Paper) $)^{1}$ 를 발간하도록 의결하였다. (윤지영 2013) 이렇듯 인지제고와 ODA에 대한 국민과의 소통의 중요성이 높아지는 시점에 한 가지 주목해야 할 것이 있다. 많은 선진원조공여국이 ODA 증액 시기에 특별히 관심과 지원을 기울인 개발교육(Development Education)이 바로 그것이다. 본 고에서는 우리나라와 같은 원조 증액의 전철을 밟은 선진원조공여국인 영국과 아일랜드의 개발교육 사례를 분석하여, 이 토대 위에서 한국 개발교육에의 정책적 함의를 살펴보고자 한다.

\section{II. 개발교육의 개념과 필요성}

개발교육이란 세계를 살아가는 사람들의 삶의 상호의존성을 인지하는 토대 위에서, 글로벌 이슈와 개발 이슈를 학습하는 교육을 말한다. 이는 단순한 지식 전달에 그치는 교육이 아니며, 세계적 관점을 통한 통합적 사고, 비판적이고 창조적인 사고를 가능케 하며, 능동적이고 참여적인 태도를 함양토록 하는 교육을 말한다. 개발교육은 1960년대 유럽의 개발 NGOs를 중심으로 시작되었다. 초창기에는 개발원조, 해외봉사, ODA에 관한 교육 및 지식전달에 그쳤던 것이 현재에는 글로벌 시민(Global Citizen)으로서의 자의식과 책임감 형성을 위한 교육으로까지 발전하여 진행되고 있는 상황이다.

개발교육이 필요한 이유로는 1) ODA에 대한 대국민 인지제고 및 지지 확보 2) 양질의 개발협력전문가 육성 3) 글로벌화된 지구를 살아가는 모두의 권리 4) Post-2015 Development Agenda 설정 및 달성에의 기여, 이렇게 크게 4가지를 꼽을 수 있다. 첫째, 개발교육은 국민들의 $\mathrm{ODA}$ 에 대한 인지제고 및 지지 획득을 위한 가장 강력한 도구 중 하나로, 선진원조공여국들은 원조 확대 시기 ODA 백서 발간과 함께, 개발교육에 대한 대대적인 지원을 아끼지 않았다. 영국은 1997 년 Tony Blair 하의 노동당(Labor Party) 정부가 정권을 잡은 후, 국제개발에 대한 강한 지지를

1) 백서는 각 정부부처에서 특정 사안에 대해 발간하는 공식 보고서로, 정부 발간보고서 중 최고 권위를 지닌다. 이는 정부 정책에 관한 정보 전달을 통해 의회와 국민의 정책에 대한 이해를 제고하고, 그에 대한 의견을 수 렴하기 위한 창구의 기능을 담당한다(KOICA ODA연구팀 2013). 
표하며, 독립적인 원조 담당부처인 국제개발부(Department For International Development, DFID)를 신설하였다. 또한 국제개발협력 정책 목표와 원칙을 수립하고, 이에 대한 국민의 의견을 수렴하고 인식을 제고하기 위해 1997년 첫 번째 ODA 백서인 '1997 세계 빈곤 퇴치: 21세기의 과제(Eliminating World Poverty: A Challenge for the 21st Century'를 발간하였다. (KOICA ODA연구팀 2013) 이 백서에서 영국 정부는 '영국의 모든 아이들은 개발 이슈를 교육 받을 수 있어야 하며, 이를 통해 향후 그들의 삶을 구성할 핵심 글로벌 이슈들을 이해할 수 있도록 한다'고 말하며 개발교육의 중요성을 강조하였다. (DFID 1999) 아일랜드 역시 이와 비슷한 양상을 보인다. 2005년 아일랜드 수상은 MDGs 달성을 위해 2012년까지 ODA/GNI 규모를 0.7\%까지 확대하기로 약속하였다. 이를 뒷받침하기 위한 개발원조 정책, 전략 수립 및 국민지지 획득의 일환으로 2006년 첫 번째 ODA 백서를 발간하였다. 이 백서에서 '정부는 아일랜드의 모든 국민이 글로벌 시민(Global Citizen)으로서의 권리와 의무에 대해 학습할 기회에 접근할 수 있도록 한다'고 천명하고 있다.

둘째, 개발교육은 양질의 개발협력전문가 육성을 위해 필요하다. 선진원조공여국의 아이들은 초등학생, 더 나아가 유아기 때부터 환경, 젠더, 불평등, 무역 등 다양한 개발 이슈를 자기 연령에 맞는 교재와 학습법에 따라 습득하고 있다. 이를 통해 국제개발협력 전반에 대한 바른 이해와 관심을 가진 양질의 개발협력전문가들이 육성되고 있으며, 이들이 주요한 국제기구 및 공여국 회의에서 의제를 선도하여 정해가고 있는 것이다. 이런 면에서 개발교육은 국제기구 과소진출국으로 국제기구에 여전히 많은 공석이 있음에도, 이에 진출할 만한 적합한 인재를 발견하기 힘든 대한민국의 현실에서 무엇보다 필요한 교육이라고 할 수 있다.

셋째, 개발교육은 개발도상국의 개발문제 해결만을 위해서 필요한 것이 아니라, 글로벌화 (Globalization)된 세계를 살아가는 지구 구성원들이 누려야 하는 권리이다. 오늘날 세계에서는 $\mathrm{HIV} / \mathrm{AIDS}$, 사스(SARS)와 같은 국경을 넘나드는 전염병, 환경 파괴로 인한 기후변화, 지구 전역을 넘나드는 투기자본으로 인해서 초래된 세계금융위기 등 주권국가 내에서는 해결이 불가능한 다양한 지구 공동의 문제가 발생하게 되었다. 개발교육은 지구촌에서 발생하는 다양한 문제들이 개인의 삶에 끼치는 영향력을 인지하고, 이에 대응하는 방법을 알리는 교육이다. 따라서 이는 단순히 개발에 종사하는 사람들 뿐 아니라 지구촌 시대를 살아가는 모든 국민들에게 필요한 교육이라고 할 수 있다. 이러한 이유로 유럽의 선진공여국에서는 개발교육을 단순한 국민들의 국제개발에 대한 인지제고 차원이 아닌, 모든 국민들이 당연히 누려야 하는 권리로 인식하고 이에 접근하고 있다.

마지막으로, 개발교육은 Post-2015 Development Agenda와 관련하여 그 중요성이 강조되고 있다. Post-2015 Development Agenda는 마감시한이 2015년인 새천년개발목표(Millennium Development Goals, MDGs) 이후에 지구공동체가 가져가게 될 개발목표를 말한다. 선진국 엘리트층에 의해 Top-down 방식으로 만들어진 MDGs와는 다르게 Post-2015 Development Agenda는 지구촌에 사는 다양한 사람들의 목소리를 담아내는 것을 목표로 하고 있다. 이를 위한 많은 국별협의 및 주제별협의가 이루어져왔고, 아래로부터의 목소리를 수렴하기 위한 다양한 방법들이 고안되어 진행되어 왔다. Post-2015 Development Agenda를 구성해가는 이러한 노력이 헛되지 않으려면, 선진국 뿐 아니라 개발도상국 내에서도 개발 및 글로벌 이슈에 대해서 알고 이에 
대해 자신의 목소리를 낼 수 있는 교육이 시행되어야 한다. 개발교육은 Post-2015의 목표를 정하는 단계에서만 중요한 것이 아니다. 오히려 목표가 설정된 이후에 더 큰 중요성을 갖는다. 지구 공동의 목표를 달성하기 위해서는 지구공동체 구성원 모두의 참여를 필요로 한다. 따라서 Post-2015 Development Agenda가 추구하는 우리가 원하는 세상(The World We Want)을 만들기 위해서 다른 무엇보다도 개발교육의 역할이 지대하다고 할 수 있다.

\section{III. 영국과 아일랜드 개발교육 사례 분석}

\section{1. 영국의 개발교육}

영국은 국제개발학을 태동시킨 국가이며, 국제개발의 선두국가(leading country)라는 명성에 걸맞게, 개발교육에서도 매우 선진화된 모습을 보여주고 있다. 영국에서의 개발교육은 1960 년대에 개발 NGOs를 중심으로 본격적으로 시작되었다. 1959년 Oxfam에 첫 개발교육 담당직원이 배치되었으며, 1970년대 중반부터는 개발교육만을 전담하는 개발교육센터(Development Education Centre, DEC)가 영국 전역에 설립되었다. (이상백, 박수연 2013)

1997 년 정권을 잡은 노동당 정부의 국제개발에 대한 굳은 의지와 전폭적인 지원 아래, 이 시기 영국 국제개발과 개발교육은 대대적인 성장을 하게 된다. 국제개발을 전담하는 정부부처인 DFID가 1997년 설립되었으며, 같은 해 첫 번째 영국 ODA 백서가 발간되었다. 특별히 이 시기 국제개발부 장관이었던 Clare Short는 국제개발에 매우 헌신된 강한 열정을 가진 인물로, 영국의 ODA/GNI 비율을 국제사회의 권고기준인 $0.7 \%$ 로 늘리고자 노력하였다. 영국의 첫 번째 백서는 1997년에 발간되었다. 이 백서에서 영국은 MDGs의 대표적인 목표들인 절대빈곤인구 절반 삭감, 기초보건 및 기초교육 증진 등을 영국이 개발원조를 통해 달성해야 할 목표로 천명하였다. 이러한 원대한 포부를 달성하기 위해서는 해외 원조에 대한 대중의 지지가 필수적이었기 때문에, 영국 정부는 1997년 백서에서 특별히 영국 내에서 해외 원조에 대한 국민들의 지지를 구축하는 것의 중요성을 강조하였다. (DFID 1999) 이러한 배경에서 영국 개발교육을 지원하기 위한 정부 펀드체제인 개발인지자금 (Development Awareness Fund, DAF)이 구축되었다. 이 자금은 개발교육을 시행하는 영국 내 작은 규모의 $\mathrm{NGOs}^{2}$ 와 $\mathrm{DEC}$ 들이 개발교육 자료 편찬, 교육 커리큘럼 개발, 세미나 개최 등의 개발교육활동을 지원하는데 사용되었으며, 이 시기 영국 개발교육이 괄목적으로 성장하는데 큰 역할을 했다.

2) Oxfam과 같은 큰 규모의 NGO들은 DAF를 받지 않고, DFID로부터 공여 받는 파트너십 펀드의 일부를 개발 교육에 활용하도록 되어 있다. 
영국 개발교육 발전에 있어서 교육부의 역할도 빼놓을 수 없다. 교육부는 2000년 개정된 정규교육과정에서 1) Global Dimension 2) Citizenship 3) Community Cohesion이 필수로 다뤄지도록 의무화하여, 개발교육이 '글로벌 시민교육(Global Citizenship Education)'이란 이름하에 정규교육과정에서 다루어질 수 있도록 했다. DFID는 이를 지원하기 위해 'Developing a Global Dimension in the School Curriculum'이라는 책자를 발간하여 공교육 차원에서의 개발교육을 장려하기 위한 노력을 기울였다. 영국은 5 세에서 18 세에 초점을 맞추어 공교육을 통한 개발교육 시행의 4 대 핵심목표를 다음과 같이 정하였다. (DFID 1999)

〈표 1〉 1997 영국 노동당 정부 하의 공교육을 통한 개발교육 4대 핵심 목표

\section{영국 공교육을 통한 개발교육 4대 핵심 목표}

1. 글로벌 이슈가 영국 공교육 커리큘럼에 포함되도록 한다.

2. 학교에서의 교육을 장려하기 위하여 양질의 교육 자료들을 제공한다.

3. 교사교육이나 개발교육 시행을 감시하고 보상을 주는 제도 등을 통해 학교를 통한 교육을 강화한다.

4. 개발에 초점을 맞추면서 Whole School이나 지역의 활동들을 장려한다.

정규교육과정 내에서 개발교육이 시행될 수 있는 방법은 다양한데, 그 중 가장 대표적인 것이 교과서 내에 개발교육과 관련한 정보를 넣는 것이다. 현재 한국에서는 사회나 지리 교과목 등에 $\mathrm{KOICA}$ 의 활동이나, 국제개발협력 활동을 넣는 방식으로 이를 시행하고 있는데, 영국은 이를 넘어서 수학, 언어 등 다양한 비전통적인 교과목 내에 개발교육을 접목하는 시도를 하고 있다. 수학과목의 경우, 전 세계 빈곤층의 숫자라던가, 질병으로 고통 받는 아이들의 숫자 등을 통계와 같은 수학문제 넣어 자연스럽게 학생들이 국제개발 이슈를 접하도록 하고 있다.

2010년 영국은 보수적 성향의 연립내각(Coalition Party)이 들어서면서, 개발교육에서도 일련의 변화를 경험하고 있다. 이러한 변화를 한 눈에 볼 수 있는 것이 바로 DAF가 종료되고 새로이 시작된 정부 펀딩 시스템인 Global Learning Programme(GLP)이다. GLP는 분명한 개발교육의 시행 목표와 이를 위한 집행체제를 구축하여 개발교육에 접근하고 있다. DAF 체제에서는 개개 개발교육 기관들이 자유롭게 개발교육을 시행하도록 하여, 큰 국가적인 그림이 부재하였다. 또한 대상층도 5 세에서 18세였다. 이에 반해, GLP는 7세에서 14세로 목표대상층을 좁히고, 구체적으로 5년 내에 Stage 2(7세-11세), Stage 3(11-14세) 연령의 학생들을 대상으로 영국 내 학교의 50\%까지 개발교육을 전파한다는 분명한 목표를 지니고 있다. GLP는 이의 시행을 위한 조직적인 집행체제를 보유하고 있다. DAF 체제에서 Triple Line Consulting Ltd.와 Think Global이 단순한 DAF 분배기능과 자료 발간이나 네트워크 기능을 담당한데 반해, GLP 체제에서는 7개의 기관이 개발교육 컨소시움(Development Education Consortium)을 이루어 민간개발교육기관들의 역량강화와 
개발교육 평가를 시행하는 역할을 담당하게 된다. ${ }^{3)}$ 이 7개의 기관 중 Pearson이라는 컨설팅 회사가 리딩(Leading) 기관이 되고, 여기에, Oxfam, Think Global, Royal Geographical Society, Geographical Association, School Network, Institute of Education(IOE)이 참여한다. Pearson은 개발교육에 대해서 잘 아는 기관은 아니지만, 유명한 컨설팅 회사로서 학교 관련된 컨설팅 사업을 잘해온 것이 부각되어 이 컨소시움의 리딩 기관이 되었다. 따라서 DFID가 Pearson 과 계약을 맺고 일을 진행하고, 다시 Pearson이 위에 언급한 6개 기관과 계약을 맺어 일을 하고 있다. 개발교육의 학문적 기능을 담당하고 있는 IOE는 영향평가 부분을 담당하고, Think Global 과 Royal Geographical Society가 교육 자료(Resources) 부분을, 학교 정체성과 관련된 Whole School 부분은 Oxfam과 Geographical Association이 맡는다. 마지막으로 개발교육 전파의 주된 기능을 할 학교 간 네트워크 체제 관리에 대한 부분을 School Network가 담당한다. (DFID 2013)

\section{〈그림 1〉 GLP의 개발교육 컨소시움(Development Education Consortium)}

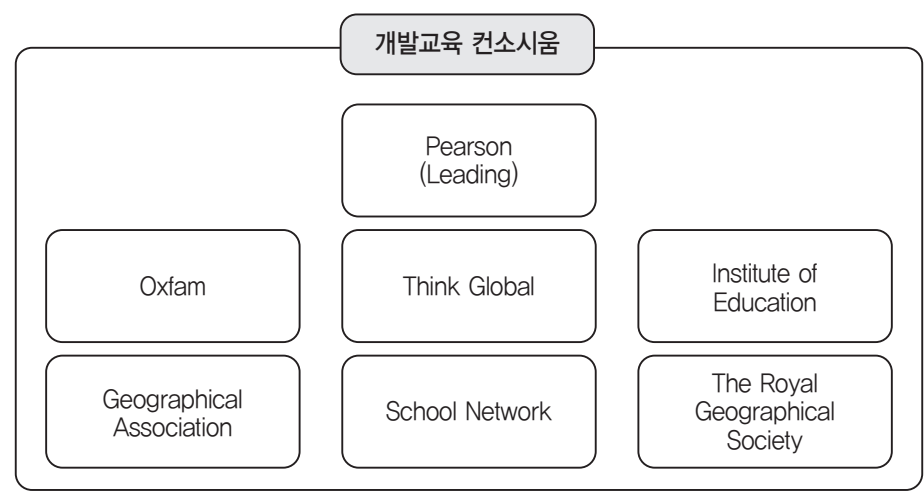

DAF 체제에서 GLP 체제로의 변화에서 보여지는 영국 개발교육 정책 변화의 주요 내용은 다음과 같다. 1) 시장주의적 접근의 강화 2) 교육평가의 강화 3) 공교육 내 교사교육을 통한 개발교육 전파이다. 먼저, GLP 체제는 DAF 체제와는 다르게 시장주의적 접근 방식을 취하고 있다. 이는 개발교육 자금의 분배방식 변화에서 드러난다. DAF 체제 아래에서는 DFID가 Triple Line Consulting Ltd. ${ }^{4}$ 와 개발교육협의체인 Think Global5)을 통해 민간 개발교육기관으로 개발교육

3) Pearson이 이끄는 개발교육 컨소시움(Development Education Consortium)은 England 지역을 위한 컨소시 움이며, DFID는 이 컨소시움에 £16 million(한화 약 281억 5,600만원)를 공여할 예정이다. Scotland, Wales, Northern Ireland에서 GLP를 시행할 기관들은 별도로 존재하나, 아직 시행주체가 확정되지 않았기에, 여기서 는 확정이 된 England를 중심으로 기술하였다.

4) Triple Line Consulting Ltd.와 Think Global은 DFID를 대신하여 DAF를 각 개발교육기관에 분배하는 역할을 감당하고 있다. Triple Line Consulting Ltd. 는 £ 10,000 £ 100,000 규모의 Major Grants를 담당하고, Think Global은 $£ 10,000$ 이하의 Mini Grants를 담당한다.

5) 개발교육기관간의 네트워크 및 이들 기관을 위한 자료 및 펀드 제공의 역할을 담당하는 개발교육협의체로 Development Education Association(DEA)에서 Think Global로 명칭을 바꾸었다. 
자금을 직접 분배하였다. 반면, GLP 체제에서는 DFID가 개발교육 자금을 개별학교에 지원하면(6), 이 학교들이 민간 개발교육기관으로부터 개발교육을 구매하게 된다. 이 방식에 의하면, 정부가 따로 각 개발교육기관의 교육의 질을 평가할 필요 없이 소비자인 개개학교가 이를 평가하고, 이에 기반하여 교육을 재구매할지 말지를 결정하게 된다. 정부의 평가 부담을 없애줄 뿐 아니라, 시장에 의해서 자연스럽게 좋은 서비스를 제공하는 기관은 더 많은 교육을 제공할 수 있게 되고, 반대의 경우는 낙후되어 시장에서 도태되기 때문에 자연스럽게 교육의 전반적인 질의 향상을 기대할 수 있게 되는 것이다. 이는 자금조달적인 면에서도 매우 긍정적으로 작용한다.

다음으로 두드러지는 변화는 교육평가의 강화이다. 현재 평가 및 성과관리는 국제개발 분야 뿐 아니라 행정학 전반에서 강조되고 있다. 이에 따라 영국 개발교육에서도 교육평가가 각광받고 있다. 이에 따라, 2010년 집권과 함께 새로 들어선 보수연립정권은 새로운 DAF 공여를 전면 종료하고 기존에 DAF로 진행된 개발교육 프로그램에 대한 평가 작업을 대대적으로 시행하였다. 또한 새로이 출범하는 GLP 체제 내에서는 시작단계에서부터 평가 시스템을 구축하는 등 교육평가에 많은 노력을 기울이고 있다. 평가 방법 또한 변화하였다. 기존 DAF 하에서는 교육과정 제공이라는 투입(Input)에 초점을 맞추어 평가작업을 시행하였다면, GLP 체제에서는 개발교육이 개발도상국 빈곤퇴치 및 학생들의 학습능력에 어떠한 영향을 미치는가에 대한 영향평가(Impact Evaluation)적 접근을 시도하고 있다.

마지막으로 영국 개발교육에서의 중요한 변화는 기존에 민간 개발교육기관을 통해서 직접 전달되던 개발교육이, 점차적으로 공교육 체계 안에서 교사교육을 통해 전달되도록 변하고 있다는 점이다. 공교육 내 교사교육을 통한 개발교육 전파를 위해서 사용되고 있는 방법이 바로 TOT(Training for Trainers) 방식이다. 즉, 이전에는 개발 NGOs 혹은 개발교육센터의 개발교육가(Development Educator)들이 학생들에게 직접 개발교육을 제공하는 방식에 집중하였다면, GLP 체제에서는 기존의 개발교육가들이 초중고 교사들에게 개발교육의 교수법을 가르친 후, 수업을 들은 교사들이 자신들의 학생들을 가르치는 TOT 방식을 강화하고 있다. 이러한 교사교육을 통한 공교육 내 개발교육 전파 방식은 다음과 같은 유익을 가진다. 기존의 DAF 체제에서는 DFID가 지속적으로 개발교육 기관으로 자금을 제공해야 하지만, 공교육을 통한 개발교육이 확산되면, DFID의 원조 예산을 절약할 수 있다는 장점이 있다. 또한, 개발교육센터 혹은 개발교육기관은 전국 각지에 골고루 분포하지 못하여 개발교육 수혜의 지역별 편차가 발생할 수 있는데, 공교육을 통한 개발교육 전파는 이러한 면을 보완해 줄 수 있다. 마지막으로, 민간을 통한 개발교육이 산발적이고 이벤트적인 성향이 강하다면, 공교육을 통한 개발교육은 지속가능하고 안정적이라는 장점을 지니고 있다.

6) GLP 체제 아래에서, DFID는 학교당 $€ 1,000$ 씩 연간 500 개 학교에 5 년간 자금을 지원하여, 총 2,500개 학 교에 개발교육이 시행되도록 한다. 
〈그림 2〉DAF 체제와 GLP 체제 비교
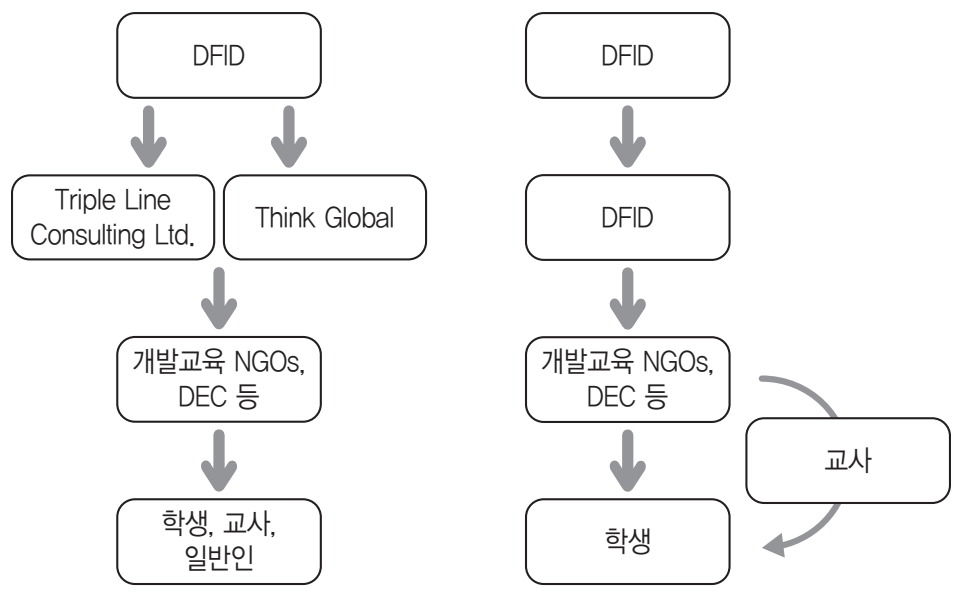

개발교육기관 및 학교로의 펀딩 시스템인 GLP 외에 DFID가 새로 추진하고 있는 또 다른 대표적인 개발교육 사업은 영국문화원(British Council)과의 협력사업인 Connecting Classrooms 사업이다. 2012년 6월부터 시작한 3개년 사업으로 영국의 학교들이 세계의 다양한 학교들과 자매결연을 맺고, 글로벌 이슈들을 학습하도록 고안된 프로그램이다. Connecting Classrooms은 DFID 에 의해서 제공되던 'Global School Partnerships Programmes'과 영국문화원의 'Connecting Programme' 두 개의 프로그램이 합쳐진 프로그램이다. 각 프로그램의 장점을 엮었으며, 두 기관이 협력하여 자금공여 및 시행을 맡게 된다. 이 프로그램에 참여하는 학교들은 온라인 플랫폼 가입, 글로벌시민교육(Global Citizenship Education) 및 ICT에 대한 교사교육, 교장을 위한 리더십 프로그램, 자매결연 학교와의 교환방문 등의 기회를 얻게 된다. 이 프로그램을 통해 향후 3년간 전 세계 5,600 개 학교들이 장기적인 협력관계를 구축하게 되며, 31,000 개의 학교들은 인터넷을 통한 공동 프로젝트(Joint Project)에 참여하게 된다. 15,000명의 교사들이 훈련을 받게 되며, 영국 외의 국가들의 3,300 명의 교사들이 리더십 훈련을 받게 되고, 6,600 개의 학교들이 영국문화원으로부터 주어지는 International School Award Status를 획득하게 된다. 이 프로그램을 위해서 DFID는 3 년간 £17 million(한화 약 300억 4,800만원)를 공여하며, 영국문화원은 £25 million(한화 약 441 억 8,800만원)를 공여한다.(DFID, 2013)

영국에서 보수적 정당은 국제개발 및 개발교육에 우호적이지 않은 것이 일반적이었다. 이러한 이유로 1979 년에 보수당이 집권했을 당시에는 이전 노동당 정부에서 시행 중이었던 개발교육 지원제도를 
폐지하였었다. 하지만 2010년 집권한 보수적 성향의 연립내각() 하에서는 David Cameron 총리8)를 비롯한 정부 및 시민사회 전반이 국제개발 및 개발교육에 대한 강한 지지를 보내고 있다. 영국정부는 유럽 전반의 경제위기에도 불구하고, $\mathrm{ODA} / \mathrm{GNI} 0.7 \%$ 달성에의 굳은 의지를 보여주고 있으며, Global Learning Program, Connecting Classroom 등 다양한 개발교육 관련 펀드를 구축하여 이에 대한 지원을 지속하고 있다. 이에 대한 주요한 이유로 들 수 있는 것이 바로 지난 40년간 영국 내에서 활성화된 개발교육의 영향이다. 이를 통해, 진보와 보수 모두가 국제개발 및 개발교육에 우호적인 태도를 갖게 되었고, 현재의 영국은 국제개발 및 개발교육에 초당파적인 지지(Cross Party Support)를 보내는 유례없는 시기를 맞이하게 된 것이다. 이는 개발교육이 끼치는 장기적인 긍정적인 영향의 중요성을 다시금 생각하게 하는 일이라고 볼 수 있다.

\section{2. 아일랜드의 개발교육}

영국과 마찬가지로 아일랜드도 원조증액 시기 국민인지제고 및 지지확보의 주된 수단으로 개발교육을 사용하였으며, 개발교육을 원조사업의 주요한 요소로 인지하고 접근하고 있다. 아일랜드는 국가적인 차원에서 개발교육에 대한 뚜렷한 방향과 목표를 지니고 있다. 아일랜드의 개발교육은 아일랜드 개발정책과 직접적으로 연동되어 있다. 아일랜드 개발원조의 목적은 빈곤퇴치와 지속가능개발이며, 아일랜드 개발교육 역시 궁극적으로 이를 실현하는 방향으로 구성되어 있다. 즉, 아일랜드 개발교육정책은 대국민 ODA 인지도 제고 및 이를 통한 ODA 지지세력 확충이라는 미시적 관점에서 벗어나, 개발교육을 통해 양질의 원조를 제공하고, 이를 통해 빈곤퇴치와 지속가능개발을 달성한다는 장기적 목표의식을 보유하고 있다.

〈그림 3〉 아일랜드 개발교육의 장단기 목표

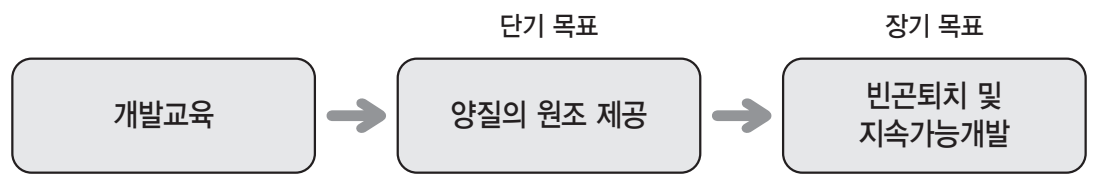

아일랜드는 이러한 장단기 목표를 달성하기 위한 뚜렷한 전략목표와 세부목표를 보유하고 있으며 이는 아래와 같다.

7) 2010년 선거에서 보수당(Conservative Party)이 305석을 차지해 제 1당이 되었으나, 과반수 의석인 325석 확보에 실패함으로 보수적 성향의 자유민주당(Liberal Democractic Party)과 함께 연립내각을 구성하였다.

8) David Cameron 총리는 UN Post-2015 Development Agenda의 기본 포맷을 형성하는 고위급패널(High Level Panel, HLP)의 공동의장 3명 중 한 명으로 이 패널이 목적한 결과물인 고위급패널 보고서를 UN 반기 문 사무총장에게 기한 내에 성공적으로 제출하는데 크게 기여한 사람으로 꼽힌다. 


\section{〈표 2〉 아일랜드 개발교육 전략목표와 세부목표}

\section{아일랜드 개발교육 전략목표}

교사와 개발교육에 종사하는 사람들에게 양질의 프로그램을 제공하고, 교육부문, NGOS, 그리고 시민사회간 의 협력을 통해 개발교육이 아일랜드 전역의 청중들에게 전파되도록 한다.

\section{아일랜드 개발교육 세부목표}

1. 개발교육과 공교육, 시민정책과 개발정책 간의 일관성을 강화하고, 유럽과 국제적 차원에서의 개발교육에 서의 우수 사례를 지원한다.

2. 개발교육가와 그들이 일하는 기관들에의 지원 강화를 통해, 양질의 개발교육을 아일랜드에 제공한다.

3. 개발교육을 아일랜드의 공식 및 비공식 교육에 통합시킨다.

4. 개발교육 활동이 국민의 인지 및 지구 빈곤과 불평등 문제의 원인, 그리고 이에 대처하는 아일랜드의 역할 에 대한 이해 수준을 제고시키는데 도움을 주도록 한다.

아일랜드는 이러한 목표들을 시행하기 위해서 개발교육과 관련된 중기전략 계획을 수립하고 이를 토대로 개발교육을 체계적으로 전파하고 있다. Irish Aid는 『Development Education Strategy Plan 2004-2007」을 발간하여, 초등교육 내의 개발교육 전파에 힘써 왔으며, 『Development Education Strategy Plan 2007-2011에서는 중등교육 내의 개발교육 전파에 집중해왔다. 이의 일환으로 Irish Aid가 주도하고 있는 'Comprehensive School Programs for Secondary Students' 는 중고등학생들을 타겟으로 한 개발교육 확산 프로그램이다. 이 프로그램은 초등학교 학생들에 대한 개발교육이 충분히 시행되었다는 판단 아래 전략적으로 중고등학생들을 타겟층으로 잡고 있다. 구체적인 내용은 2016년까지 1 million 유로(한화 약 14억 5,600만원)를 개발교육기관에 공여하여 이들이 아일랜드 전역의 700여개 학교의 50-70\%까지 개발교육을 확산하도록 하는 것이다. 즉, 기존의 방과 후 활동이나 개발교육기관을 학생들이 직접 방문하여 개발교육을 받는 방식에서 벗어나, 학교 공교육 체계 안에서 개발교육을 학습할 수 있도록 하는 것을 목표로 하고 있다.

공교육을 통한 개발교육 전파를 위해서 Irish Aid가 특별히 초점을 맞추고 있는 대상은 예비교사이다. Irish Aid는 예비교사에 대한 개발교육 시행을 위해서 'Development and InterCultural Education(DICE) Project'를 구상하여 실시 중이다. 이는 아일랜드 사범대학의 예비교사 교육과정의 주요한 요소로 개발과 다문화 교육을 포함시키는 프로젝트이다. "Development Education Strategy Plan 2004-2007』의 대상은 초등학교 교사들이었는데, 이 중기 전략에 의거하여 Irish Aid의 개발교육팀은 미래의 초등학교 선생님이 될 예비교사들이 개발교육 수업을 모두 이수하도록 하는데 성공했다. 이러한 토대 위에서, ${ }^{\circledR}$ Development Education Strategy Plan 2007-2011」은 중등학교의 개발교육 강화를 목표로 삼고 있는 것이다. (Irish Aid 2006)

영국과 마찬가지로 아일랜드에서도 개발교육은 지속가능한 시장주의적 체제로 변모 중이다. 이전에 개발교육기관들에게 정부가 자금 지원을 지속적으로 제공했던 방식에서 벗어나, 독자적으로 자생할 수 있는 구조를 만들어가고 있다. 즉 계속해서 민간 개발교육기관에 자금을 제공해 줄 수 없을 때를 대비하여, 개별 기관들이 충분한 경쟁력을 갖추어 교육 시장에서 살아남도록 만들고 있다. 
영국과 마찬가지로 아일랜드도 『Development Education Strategy Plan 2012-2015』에서 기존의 개발교육기관에의 직접 펀딩 체제를 거두고, 지역사회기관, 학교, 대학 등에 펀드를 제공하여, 이들 기관들이 개발교육기관으로부터 개발교육 서비스를 구매하는 방식으로 전환하고 있다. 이를 통해 장기적으로 개발교육에의 자금 출처가 원조기관이 아닌 개별학교가 되도록 하는 것이 양 국가의 공통적인 개발교육 정책인 것이다.

Irish Aid가 시행하고 있는 흥미로운 개발교육 프로그램 중 하나가 'Our World Irish Aid Awards Project'이다. 이는 8세-12세 학생과 교사들이 MDGs 등 개발과 관련된 주제로 자유로운 프로젝트를 실시하고, 이를 심사하여 상을 주는 제도이다. 2013년에는 'Education for All the World's Children'이란 주제로 실시되었으며, 아일랜드 전역의 1,000여개 학교가 프로젝트를 신청하였고, 3 만 명의 학생들이 참가하였다. 지역 예선을 거쳐 전국대회 본선을 거쳐 최종 승자를 가리게 된다. 이러한 프로그램을 통해 아일랜드 전역의 교사와 학생들이 자연스럽게 MDGs 이슈를 배우고 전파하는 역할을 감당하게 되는 것이다.

2008년 아일랜드는 금융위기로 인한 열악한 경제상황에서도 해외원조에 대한 굳은 의지를 잃어버리지 않고 있다. 물론 원조자금은 국가도산의 위기까지 치달은 어려운 상황 하에서 2008년 920 million 유로(한화 약 1조 3,398억)에서 2013년 623 million 유로(한화 약 9,073억)로 대폭 삭감되어 $\mathrm{ODA} / \mathrm{GNI}$ 비율이 $0.5 \%$ 이하로 떨어졌지만9), 아일랜드 정부는 경제가 회복 되는대로 UN 이 제시한 ODA/GNI $0.7 \%$ 수준으로 원조자금 규모를 늘릴 것이라는 입장을 견지하여 변함없는 원조에 대한 의지와 지지를 보여주고 있다. 이런 일반 대중들의 지지와 영국과 마찬가지로 개발 및 개발교육에 아일랜드가 보내는 초당파적인 지지는 지난 25 년간의 집중적인 개발교육이 맺은 성과라고 볼 수 있다.

\section{IV. 한국 개발교육에의 정책적 함의}

현재까지 살펴본 영국과 아일랜드 개발교육 정책 사례에서 도출해낼 수 있는 한국 개발교육에의 정책적 함의는 다음과 같다.

첫째, 공교육을 통한 개발교육 강화가 필요하다. 현재 한국에서 개발교육은 크게 3 가지 루트로 이루어지고 있다. 1) 개발 NGOs 등 민간개발교육 유관기관이 글로벌시민교육(Global Citizenship Education), 나눔교육 등의 일환으로 시행하는 다양한 이벤트, 초중고 출강 등 2) KOICA ODA 교육원, 지구촌체험관, 홍보실, 연구팀 등을 통해 이루어지는 대국민 인지제고 활동 및 ODA교육 3) 사회, 지리, 영어 교과목 교과서 내에 국제개발협력 및 $\mathrm{KOICA}$, 국제기구 활동 소개 등이 그것이다. 하지만 대부분의 교육은 매우 단발적이며 뚜렷한 목표와 체계 없이 이루어지고 있는 것이 현실이다.

9) 2012년 한국의 ODA/GNI 비율은 $0.14 \%$ 이다. 
영국의 경우, 1997 년 DFID 설립과 함께 영국 공교육을 통한 개발교육의 4 대 핵심 목표를 정하고 공교육 내 개발교육 확산에 많은 노력을 기울여왔다. 아일랜드도 개발교육 중기 전략을 통해 초등학교 내 개발교육 확산, 중등학교 내 개발교육 확산 등 점진적으로 개발교육을 아일랜드 전역에 파급하는 노력을 기울여왔다. 한국 공교육 내에서 개발교육을 확산하는 것에도 여러 방법이 있다. 먼저 교과서 및 교과과정에 국제개발 및 국제개발 기관에 관한 내용을 확대하는 것이다. 그간 국무총리실 및 $\mathrm{KOICA}$ 홍보실의 노력으로 사회, 지리, 영어 교과 등에 관련 내용이 실려 있으나, 아직 충분하지 않은 상황이다. 또한 영국의 사례에서 살펴본 것처럼, 사회, 지리 등 직접적으로 국제개발과 관련 있는 교과목 외의 타 교과에도 창의적으로 국제개발에 대한 내용을 적용시키는 노력이 필요하다. 현재 $\mathrm{ODA}$ 교육원도 기존의 1 회성 강의제공에서 벗어나 초중고교내 개설된 ODA 및 국제개발에 특화된 동아리에 총 5 회 차의 강의를 제공하고 있다. 이러한 동아리 지원학교 수를 지속적으로 늘려나갈 뿐 아니라, 경제학교와 시민학교와 같은 방식으로 'ODA 학교', '국제개발협력 학교' 등의 시범학교를 운영하는 것도 좋은 방안이라 할 수 있다. 또한 진로할동, 봉사활동, 자율활동 등의 창의적 체험활동 시간을 통해서 개발교육 전파가 가능한 점을 기회로 삼아, 기존에 이루어졌던 단발성 $\mathrm{ODA}$ 특강이 아닌, 심도 있고 지속가능한 개발교육 전파 시행을 고려해보아야 한다.

둘째, 교사교육을 통한 개발교육 강화가 필요하다. 영국의 경우, GLP 체제 하에서 전략적으로 교사들을 통한 공교육 내 개발교육 강화를 핵심 전략으로 삼고 접근하고 있다. 한국의 경우, 몇몇 개발 $\mathrm{NGOs}$ 를 중심으로 교원연수가 시행되고 있으며, KOICA ODA교육원도 2012년 첫 교사 특별교육을 개설하고, 2013년부터 교원연수 학점 부여 과정으로 전환하여 이를 진행하고 있다. 2012년 1회 과정의 경우, 교원연수 학점 등의 혜택이 부재하였음에도 100 명 정원이 하루 만에 마감되었고, 2014 년 1월에 개설된 과정의 경우, 35 명 정원에 수강대기자가 70 명이 넘는 등 국제개발협력에 대한 교사들의 지대한 관심을 엿볼 수 있었다. 2012년 연 2회 개설되는 과정을 2013년 연 3회로 확대 개설하였으나, 증가하는 교사들의 국제개발협력에 대한 관심을 고려해 보았을 때 이 역시도 수요를 충족하는데 충분하지 못할 것으로 보인다. 따라서, 교원연수과정 확대와 함께, 이를 시행하는 타 개발 $\mathrm{NGOS}$ 와의 공동교육, 국제이해교육 및 지속가능개발교육을 시행하는 UNESCO와의 협력방안 구축 등 다양한 루트로 교사들의 수요를 충족할 방안 마련이 필요하다. 실제 교과서 내에 국제개발협력 및 $\mathrm{KOICA}$, 국제기구에 관한 내용이 실려 있음에도 이에 대한 지식 부족으로 이를 충분히 학생들에게 교육하지 못한다는 교사들의 상황을 고려해볼 때, 공교육 내 개발교육 확산을 위해서는 교사들에 대한 개발교육 강화가 무엇보다 시급하다 할 수 있다. 이를 위해 한국에서 적용할 수 있는 것이 바로 아일랜드의 예시이다. 아일랜드의 경우, 사범대학 예비교사들에게 다문화 및 개발교육을 필수적으로 가르치는 DICE 프로젝트를 시행함으로 교사를 통한 개발교육 전파에 힘을 쏟고 있다. 우리도 대학교 국제개발협력 이해증진사업 참여대학 중에서 사범대학의 비중을 높이는 방식 등을 통해 예비교사들에게 국제개발협력 교육을 시행하는 노력이 필요하다.

셋째, 민간을 통한 개발교육 펀드 마련이 필요하다. 영국과 아일랜드의 경우, 개발교육 확산에 가장 중추적인 역할을 감당한 것은 개발 $\mathrm{NGOs,} \mathrm{개발교육센터,} \mathrm{개발교육협의체} \mathrm{등의} \mathrm{민간}$ 개발교육기관이다. 이들은 개발교육 실시, 개발교육 교재 제작, 교사연수 등 다방면의 개발교육을 
실행하며, 전반적인 개발교육의 질을 높이는데 중추적인 역할을 감당해왔다. 이들 기관들의 이러한 다채로운 활동 이면에는 이들 기관들을 지원해 온 정부기관의 노력이 있었다. 영국은 DAF를 통해 다양한 개발교육기관에의 아낌없는 지원을 펼쳐왔으며, 아일랜드의 경우도 'Development Education Grants Scheme'이란 이름 아래 민간 개발교육기관 펀드 체제를 구비하고 있다. 우리나라의 경우, 2010년 1억 7천만 원을 12 개 민간단체에 지원하여, 다양한 개발교육 활동을 장려하였으나, 이는 단년도 사업에 그쳐 장기적인 성과를 산출해낼 수가 없었다. 영국 DAF의 경우 민간단체들은 개발교육사업을 위해 최대 3년까지 지속적인 펀드를 받을 수 있었고, GLP의 경우는 5 개년 프로젝트로 이루어진다. 양질의 산출물과 지속적인 영향력을 위해서는 이렇게 장기적으로 지속되는 펀드 제공이 필수적이다. ODA교육원의 인력과 시스템으로는 개발교육의 전국적인 확대에 한계가 있는 점을 고려하여, 민간 개발교육기관으로의 펀드 제공과 협력관계 구축을 통해 전략적으로 개발교육을 확산시킬 필요가 있다. 민간에의 개발교육 펀드 마련이 필요한 또 다른 이유가 있다. 본문에서 영국의 경우 교사교육 강화를 통한 공교육 내 개발교육 확산이 현재의 주요한 트렌드라는 점을 살펴보았다. 하지만, 한국은 이를 바로 적용할 수 있는 상황이 아니다. 이러한 TOT 방식이 가능하려면, 교사집단을 훈련할 충분한 역량을 지닌 개발교육가와 전문기관이 존재하여야 한다. 영국의 경우는 지난 반세기간의 집중적인 국가적 지원과 민간차원의 노력에 기반하여, 이러한 양질의 인력과 교육기자재 등을 보유하고 있다. 하지만, 한국의 경우는 학교가 개발교육 서비스를 민간으로부터 구매하고자 할 때, 혹은 교사교육을 받으려고 할 때, 이를 시행할 수 있는 인력과 기관이 매우 희소하다. 따라서 공교육을 통한 개발교육 전파 확산에 노력을 기울이는 만큼 현 시점에서는 민간 개발교육 섹터를 충분히 양성하기 위한 민간 기관에의 개발교육 펀드 지원이 절실하다고 할 수 있다.

넷째, 개발교육에의 중장기 정책 및 전략이 필요하다. 영국과 아일랜드 모두 자국의 개발정책과 연동된 개발교육 정책, 전략 그리고 이에 대한 구체적인 목표들을 보유하고 있다. 아일랜드 Irish Aid 의 경우는 구체적인 전략목표에 더불어 이를 시행할 세부목표까지 지정하고 있으며 4-5년 단위로 중기계획을 수립하여 이를 기반으로 체계적으로 개발교육을 시행하고 있다. 이들 국가들은 또한 개발교육을 위한 별도의 모니터링과 평가 시스템까지 구축하고 있는 상황이다. 이에 반해 한국의 개발교육은 아직까지 이 모두가 부재한 상황이다. 현재 초중고 교과서에 국제개발협력과 KOICA, 국제기구, 글로벌 이슈 등 개발교육과 관련된 내용들이 게재되어 있지만, 이것이 장기적인 안목과 구체적인 개발교육 로드맵 속에서 이루어지고 있다고 보기는 어렵다. 게다가 정부차원은 물론 민간기관에서 행해지는 개발교육도 기관 홍보나 기부금 증액을 위한 방편으로 개발교육이 활용된 경우가 많았다. 목적이 국제개발협력의 인지제고인 경우도, 국내 및 국제사회의 개발 정책과 연동된 전략적인 접근이라기보다는 교육과정 개설이라는 일회성 지원으로 시행되어져 왔다. 물론 영국과 아일랜드 역시 개발교육의 성장 단계에서 이러한 과정을 거쳐 현재에 이르렀다. 하지만 한국이 후발주자로서의 이점을 최대한 활용하기 위해서는 개발교육 활성화 단계 이전에 개발교육의 중장기 정책, 전략, 실행체계, 모니터링과 평가 시스템 구축에 대한 고민이 필요하다. 


\section{V. 나가며}

개발원조를 대폭 확대하던 시점의 선진공여국 정부가 전략적으로 중점을 두었던 것이 개발교육이었다는 것을 고려한다면, 영국과 아일랜드와 마찬가지로 $\mathrm{ODA}$ 를 대대적으로 증가시키고 있는 현재 한국에서 개발교육은 선택이 아닌 필수로 다루어져야 하는 분야인 것은 부정할 수가 없다. 무엇보다 원조가 급증하던 시기에 국민의 지지와 이해제고를 위해 첫 백서를 발간하였던 영국과 아일랜드처럼 한국 역시 현재 첫 백서를 발간하려는 시점에 와있다. 따라서 국민들의 인지제고와 지지확보에 가장 중추적인 역할을 하는 개발교육의 중요성은 아무리 강조해도 조금도 지나침이 없다 하겠다.

교육은 백년지대계라는 말이 있다. 이는 단순히 한국 국내의 교육에만 한정된 것은 아니다. 빠른 속도로 국제개발계의 핵심멤버로 자리잡아가고 있는 한국은 현재 급증하는 예산과 사업에 비해 이를 집행할 수준 있는 핵심역량을 지닌 인재의 부족으로 어려움을 겪고 있다. 이 문제를 해결하기 위해서 $\mathrm{KOICA}$ 는 $\mathrm{ODA}$ 교육원을 설립하여 사업참여자를 대상으로 한 교육을 실시하고 있고, 각 대학들은 글로벌 리더를 표방하며 다양한 교육과 프로그램들을 실시하고 있다. 하지만, 이런 단기적 접근을 통해서는 국제개발협력을 어린 시절부터 체계적으로 습득하여, 개발 이슈를 평생의 화두로 삼고 고민하며 자라나는 선진공여국 전문가들의 열정과 지식을 따라잡기에는 불가능하다. 진정한 글로벌 리더를 키우기 위해서는 단순히 영어실력을 늘리고, 해외경험을 늘리고, 단기간의 교육을 받는 것으로는 충분하지가 않다. 우리가 살아가는 지구가 겪고 있는 문제, 인류 전체가 당면하고 있는 다양한 문제를 어린 시절부터 충분히 배우고 고민하고, 이를 실천하려는 노력을 삶으로 체득하는 시간이 필요하다. 개발교육은 이러한 맥락에서 현재 대한민국이 가장 필요로 하는 교육 중 하나인 것이다. Post-2015 Development Agenda의 핵심 키워드는 우리가 원하는 세상(The World We Want)이다. 지난 반세기간의 국제개발의 아젠다는 DAC 선진공여국을 중심으로 구축되어 왔으며, 그 이전 세계질서는 강대국을 중심으로 이루어져 왔다. 지금까지 해온 대로 그들이 원하는 세상(The World They Want)을 살아갈 것인가. 아니면 우리가 중심이 되어 세계와 함께 우리가 원하는 세상 (The World We Want)을 만들어갈 것인가는 오늘 우리의 교육에 달려있다. 


\section{〈참고문헌〉}

국무조정실 · 국무총리비서실 (2010)『국제개발협력 선진화 방안』, 서울: 국무조정실 · 국무총리비서실.

윤지영 (2013). “시민사회가 바라는 ODA 백서 방향”, 국제개발협력 2013년 제4호. 성남: 한국국제협력단.

이상백 (2009). “한국의 국제개발협력 인지제고 및 교육현황과 과제”, 국제개발협력 2009

년 제 3호. 성남: 한국국제협력단.

이상백, 박수연 (2013).『영국과 아일랜드 개발교육 이야기』, 성남: 한국국제협력단.

전규석 (2013). “소통하는 공적개발원조”, 국제개발협력 2013년 제4호. 성남: 한국국제협력단.

전호윤 (2004). “지구시민 육성을 위한 글로벌문제의 수업구성 연구: Betty A. Reardon의 인권교육을 중심으로”, 사회과교육 2004. 제 43권 2호, pp.27-45.

최은봉, 박명희 (2006) “일본 $\mathrm{NGO}$ 의 개발교육: 지구시민의식의 강화와 대안모색", 일본연구논총 제23호 (2006. 여름) pp.329-367. 1225-3219 KCI.

$\mathrm{KOICA} \mathrm{ODA}$ 연구팀 (2013). “선진공여국의 ODA 백서 기능과 역할 및 발전양상”, 국제개발협력 2013년 제4호. 성남: 한국국제협력단.

DFID (1999). 『Building Support for Development: DFID Strategy Paper $\_$, London: DFID.

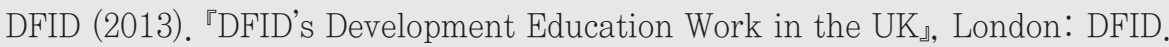

DFID (2013). 『Overview of Global Learning Programme』, London: DFID.

Irish Aid (2006). "Irish Aid Development Education Strategy Plan 2007-2011』,

Dublin: Irish Aid.

Institute of Education, Development Education Research Centre 웹사이트 http://www.ioe.ac.uk/research/150.html

Irish Aid 'Our World Irish Aid Awards' 웹사이트

http://www.dci.gov.ie/teaching-and-learning/our-world-irish-aid-awards/ 